\title{
Computational modeling of spinal neural circuits involved in transition to hopping pattern in EphA4 knock-out mice
}

\author{
Natalia A Shevtsova ${ }^{*}$, Ole Kiehn², llya A Rybak \\ From Twenty Second Annual Computational Neuroscience Meeting: CNS*2013 \\ Paris, France. 13-18 July 2013
}

According to resent studies [1,3] the spinal cord neural circuits involved in left-right coordination of locomotor activity include (a) excitatory and inhibitory commissural interneurons (CINs) with axons crossing the midline and (b) excitatory (glutamatergic) interneurons with ipsilateral axon projections activating CIN pathways. The distribution and guidance of axonal projections of the glumatergic neurons during development critically depend on the EphA4 receptors, so that in EphA4 knockout $(\mathrm{KO})$ mice the normal left-right alternating pattern of walking is replaced with a hopping gait [3]. Isolated spinal cord preparations from EphA4 KO mice also exhibit a synchronized left and right locomotor activity [3]. The pharmacological enforcement of inhibition recovers the normal left-right alternating locomotor pattern in these preparations [3]. It was suggested [2] that switching to a left-right synchronized hoping pattern in the EphA4 $\mathrm{KO}$ mice might result from an abnormal midline crossing of axons of glutamatergic neurons that are normally distributed ipsilaterally. This suggestion has been directly confirmed in anatomical studies [4]. To further evaluate this idea we developed a computational model of neural circuitries in the spinal cord with left and right rhythm generators (RGs) containing sub-populations of EphA4positive excitatory neurons projecting to the populations of CINs responsible for left-right alternation (see Figure 1). The model includes interacting populations of spinal interneurons modeled in the Hodgkin-Huxley style. To simulate changes in the EphA4 KO spinal circuits, the axons of the EphA4-positive neurons were redistributed and partly redirected to the contralateral side. As a result,

\footnotetext{
* Correspondence: Natalia.Shevtsova@drexelmed.edu

'Department of Neurobiology and Anatomy, Drexel University College of Medicine, Philadelphia, PA, USA

Full list of author information is available at the end of the article
}

the excitatory interactions between left and right RGs overcame their inhibitory interactions hence synchronizing their activity resulting in a hopping-like output pattern. A subsequent increase of inhibition in the model could recover the normal left-right alternating pattern.

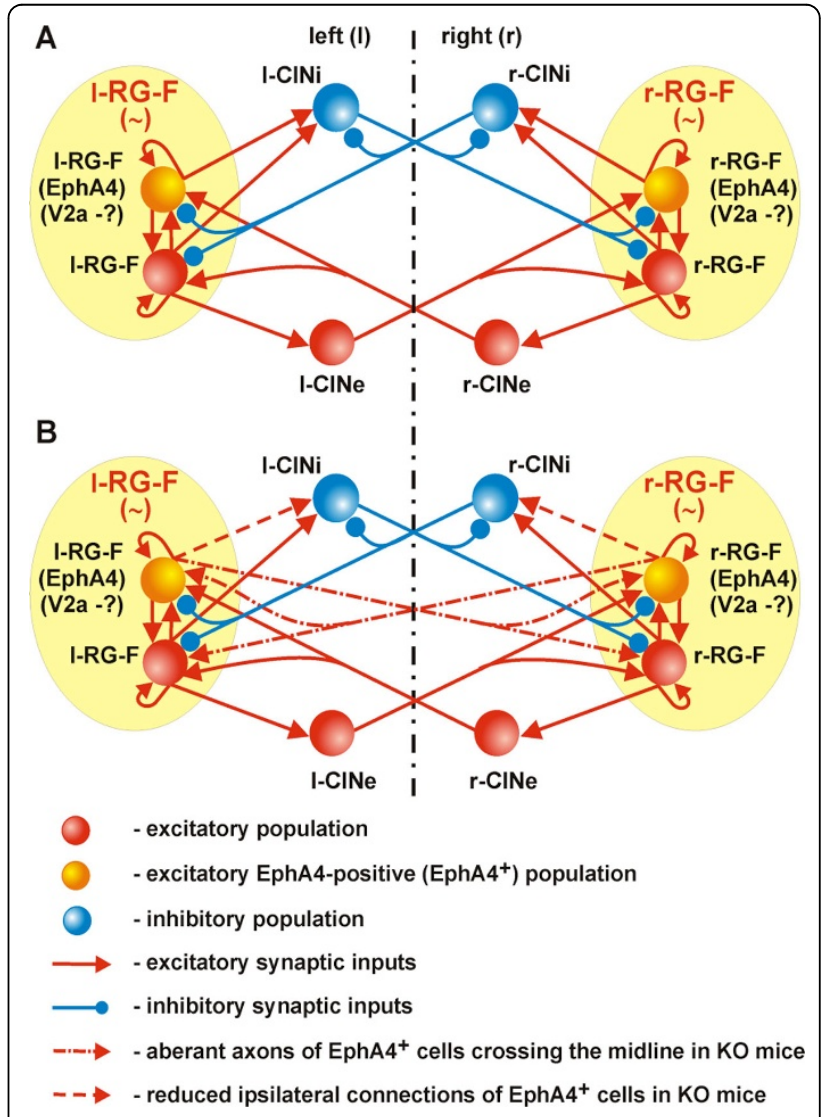

Figure 1 Schematic of spinal circuits in the model for a normal (A) and EphA4 KO (B) 
The model proposes a mechanistic explanation for the hopping gait in EphA4 KO mice and provides insights into the organization of the locomotor central pattern generator.

\section{Acknowledgements}

Supported by NIH R01NS7323 (Shevtsova, Rybak) and ERC advanced grant, Söderberg Foundation (Kiehn).

\section{Author details}

${ }^{1}$ Department of Neurobiology and Anatomy, Drexel University College of Medicine, Philadelphia, PA, USA. ${ }^{2}$ Department of Neuroscience, Karolinska Institute, Stockholm, Sweden.

Published: 8 July 2013

\section{References}

1. Crone SA, Quinlan KA, Zagoraiou L, Droho S, Restrepo CE, Lundfald L, Endo T, Setlak J, Jessell TM, Kiehn O, Sharma K: Genetic ablation of V2a ipsilateral interneurons disrupts left-right locomotor coordination in mammalian spinal cord. Neuron 2008, 60:70-83.

2. Kiehn O: Locomotor circuits in the mammalian spinal cord. Ann Rev Neurosc 2006, 29:279-306.

3. Kullander K, Butt SJ, Lebret JM, Lundfald L, Restrepo CE, Rydstrom A, Klein R, Kiehn O: Role of EphA4 and EphrinB3 in local neuronal circuits that control walking. Science 2003, 299:1889-1892.

4. Restrepo CE, Margaryan G, Borgius L, Lundfald L, Sargsyan D, Kiehn O: Change in the balance of excitatory and inhibitory midline fiber crossing as an explanation for the hopping phenotype in EphA4 knockout mice. Eur J Neurosci 2011, 34:1102-1112.

doi:10.1186/1471-2202-14-S1-P339

Cite this article as: Shevtsova et al: Computational modeling of spinal neural circuits involved in transition to hopping pattern in EphA4 knock-out mice. BMC Neuroscience 2013 14(Suppl 1):P339.

\section{Submit your next manuscript to BioMed Central} and take full advantage of:

- Convenient online submission

- Thorough peer review

- No space constraints or color figure charges

- Immediate publication on acceptance

- Inclusion in PubMed, CAS, Scopus and Google Scholar

- Research which is freely available for redistribution

Submit your manuscript at www.biomedcentral.com/submit
Ciomed Central 